\title{
精神疾患創薬研究における バイオインフォマティクスの役割
}

要約 : 精神疾患領域には大きなアンメットメディカル ニーズが残されており, 治療薬開発や創薬標的探索に 向けた研究が企業やアカデミアで行われているが, そ の基礎となる疾患の発症分子メカニズムさえも未だに 不明な部分が多い. 近年のゲノム解析機器のハイスル ープット化に伴い, 一塩基多型（SNP）を用いた GWAS（ゲノムワイド関連解析）が開発され，精神疾 患分野においても数千人以上の大規模患者集団を用い た疾患関連遺伝子探索に関する研究成果が数多く報告 されている。統合失調症においては, TRIM26や TCF4 等の遺伝子や miRNAの関与が見出され, これら を含めた新たなメカニズムが検討されつつある。また， 次世代シーケンサーの急速な発展によって, 一塩基変 異 (SNV) やコピー数多型 (CNV) といった個人毎の 稀な変異を対象とするエクソーム解析や全ゲノム配列 解析といった技術も開発され, これらからも統合失調 症患者で ARC の複合体や NMDA 受容体複合体に変異 が多い等の一定の成果が得られつつある. 動物モデル などを用いる精神疾患に対する従来の研究手法には限 界もあり, 今後の新機軸の一つとして, 患者のゲノム 情報を中心とし, 遺伝子発現等の既存情報をバイオイ ンフォマティクス技術を用いて統合解析し, 発症メカ ニズムの解明や創薬標的の探索に取り組む流れが現在 注目されている. また，バイオインフォマティクス技 術は, 既存薬や開発中の化合物について新たな適応疾 患を探索するドラッグリポジショニングにも応用され ている。新たな適応疾患は臨床開発時や市販後の臨床 研究で明らかになる場合が多いが，早期にその可能性 を見いだすことが製薬企業には重要であり，この解析 にバイオインフォマティクスは欠かせないツールとな りつつある。本稿では精神疾患創薬研究におけるバイ
オインフォマティクスの活用として, 新規創薬標的の 探索とドラッグリポジショニングの 2 つの観点から最 新の知見を紹介する.

\section{1. 創薬におけるバイオインフォマティクスとは}

バイオインフォマテイクスとは広義には様々な生物 学に関する多量の情報をコンピューターにて解析し, 何らかの新たな知見を得ることである。近年, 生命科 学研究において, オミクス技術の進展, 特に配列情報 を産出する次世代シーケンサー等のハイスループット 機器の普及により，大量の生物情報データが公共デー タベースに蓄積されつつあり，これらの情報を整理す るバイオインフォマティクスの役割が増大している.

製薬企業においてバイオインフォマティクスは, 創 薬標的探索やバイオマーカー探索から, 安全性試験に おける毒性予測, 臨床開発におけるファーマコゲノミ クス解析等に応用されている. FDAが, 医薬品の成功 確率の低下, いわゆるパイプライン問題を解決するた めに2006 年に発表したクリティカルパス計画では, バイオマーカーの開発や臨床試験の効率化のほか, 「バイオインフォマティクスの活用」が課題として提 示されており (1), 今後創薬プロセスにおいて益々バ イオインフォマティクスの重要性が増すことが予想さ れている.

\section{2. ヒトゲノム情報からの創薬標的探索アプロ ーチ}

バイオインフォマテイクスが創薬研究において利用 される場面の一つは創薬標的の探索である. 創薬標的 の探索には様々なアプローチがあるが, 疾患モデル動 物やヒトの脳サンプルを対象にした mRNA，タンパク

キーワード：バイオインフォマティクス, 創薬標的探索, GWAS, ドラッグリポジショニング

大正製薬株式会社 化学研究所化学資源研究室（†331-9530さいたま市北区吉野町 1-403）

E-mail: y-kuwahara@so.taisho.co.jp 原稿受領日：2014 年 8 月 18 日，依頼原稿

Title: Role of bioinformatics in research and development for psychiatric disorders

Author: Yusuke Kuwahara, Tore Eriksson, Katsuki Tsuritani 
質および代謝物といった分子の網羅的な測定を行うオ ミクス技術（トランスクリプトミクス，プロテオミク ス，メタボロミクス）においては多くの研究機関で実 施されているにも関わらず，新規の創薬標的が同定さ れ，創薬プロセスまで進展した例はあまり多くはない． その原因は, これら分子の挙動が疾患の進行した後の 結果を反映しているに過ぎないこと, 採取時の環境に 影響を受けやすいこと, 従うべき法則が存在しないた め実験誤差と真のデー夕を分離できないことなどが挙 げられる。

一方, ゲノムにおいては, 2003 年にヒトゲノムが解 読されて以降，一塩基多型（SNP） マイクロアレイに よるハプロタイプデータの蓄積, 次世代シーケンサー を用いた一塩基変異 (SNV) やコピー数多型 $(\mathrm{CNV})$ の探索手法の確立等, ゲノムの多様性を明らかにする 研究手法が急速に進展し, 創薬標的探索の環境が整つ てきている.ゲノム情報は環境に対して比較的安定で あり, ハーディー・ワインベルグ平衡などの数学的な 法則に従うため, 誤差と真のデー夕を分離できるなど 統計解析面で勝れた性質を持つ.さらに, 精神疾患に おいては, 統合失調症や自閉症スペクトラム障害など では比較的遺伝率が高いことが報告されており $(2,3)$, 個人レベルのヒトゲノム情報を積極的に利用すること により，精神疾患に対する新たな創薬標的が見出され る可能性が高いと考えられる.

ヒトゲノム情報を解析する上で普及している技術は, ありふれた疾患の原因は共通の変異であるという Common disease-common variant 説 $(\mathrm{CDCV}$ 説）のも と, $1 \%$ 以上の比較的頻度の高い SNP を用いる GWAS （ゲノムワイド関連解析）である。精神疾患分野にお いては，国際コンソーシアムによる大規模な解析を含 めて数多くの研究成果が報告されている(4-6). 統合 失調症では The Schizophrenia Psychiatric GWAS Consortiumによって, 様々な研究機関で実施された GWAS が統合解析され, TRIM26 や TCF4 といった既 知の遺伝子のほか, MIR137 を含む 5 つの新しいゲノ ム領域の関連が報告された。 MIR137 はタンパク質に 翻訳されない miRNAであるが, 双極性障害との関連 が示唆されている CACNA1Cを直接制御するとの報告 がある (7). 双極性障害においても Psychiatric GWAS Consortium Bipolar Disorder Working Group によって 複数の GWAS の統合解析が行われ, 既知の CACNA1C 以外にも新たに OZD4 との関連が報告された(5)。こ のように GWASからは, 精神疾患の原因となりうる遺 伝子の知見が多く得られている.

一方，比較的最近注目されている技術は，ありふれ
た疾患の原因は個人毎に異なるというCommon disease-rare variant 説 (CDRV 説) のもと, 次世代シ ークエンサー等を用いて de novo 変異のような稀な頻 度の SNV や CNV を探索するゲノム配列解析である. このような稀な変異を探索した事例として三井らのグ ループが報告した孤発性パーキンソン病患者の GBA 遺伝子変異解析の研究が挙げられる(8). 弧発性パー キンソン病患者の GWAS の解析では, これまでオッズ 比 1.1 から 2.4 程度のゲノム変異しか見出されていな かったが, 蓄積された知見からゴーシェ病の原因遺伝 子でもある $\mathrm{GBA} の$ 弧発的な変異を調べたところ, GBAのいずれかの変異を保有している率は, 弧発性パ ーキンソン病患者で $9.4 \%$ (534 人中に 50 人), 正常対 照者で $0.4 \%$ （544 人中に 2 人）であり, そのオッズ比 は約 6.5 であった。これは $\mathrm{CDCV}$ 説を根拠とする GWAS では見出せなかった成果である。また，ゲノム 配列解析の手法の一つであるエクソーム解析を用いて 統合失調症を対象にした研究結果が複数報告されてい る. エクソーム解析とはゲノムの中でタンパク質をコ ードするエクソン部分のみの配列決定を行う手法であ る. Formerらは 623 組のトリオ（統合失調症患者と その両親）のエクソーム解析の結果, 細胞骨格関連夕 ンパク質である ARC の複合体, NMDA 受容体複合体 および脆弱性 X症候群原因遺伝子であり, RNA 結合夕 ンパク質である FMRP1のターゲットにおいて de novo 変異が有意に多いことを見出した (9).また, Purcell らは 2543 人の正常人と 2536 人の統合失調症 患者のエクソーム解析によって, ARC と FMRP1 の夕 ーゲット遺伝子に変異が多いことを明らかにした (10). FMRP1 は自閉症スペクトラム障害の原因遺伝子であ ることも知られており, エクソーム解析により統合失 調症と自閉症スペクトラム障害の発症メカニズムが一 部共通であるという新たな知見が得られつつある。

しかし GWAS やゲノム配列解析の結果からだけで は創薬標的を見出すことは困難である。これらの解析 から得られるのはあくまで疾患の発症や進行に影響の 強い遺伝子であり，それらが，必ずしも疾患の治癒や 改善を目指す薬の創薬標的と同一とは限らない. 見出 された遺伝子群がどのように協調して機能し, 疾患の 発症メカニズムに関与しているか, さらにこれらのメ カニズムの中には創薬標的が含まれるかを解析するた めには，遺伝子間の相互作用情報など様々な既存の情 報を用いたバイオインフォマティクス解析が不可欠で ある（図 1)。Gilman らは統合失調症の患者の GWAS やゲノム配列解析で得られた疾患関連遺伝子に対して, 独自に開発したツールである NETBAG+を用いたネ 


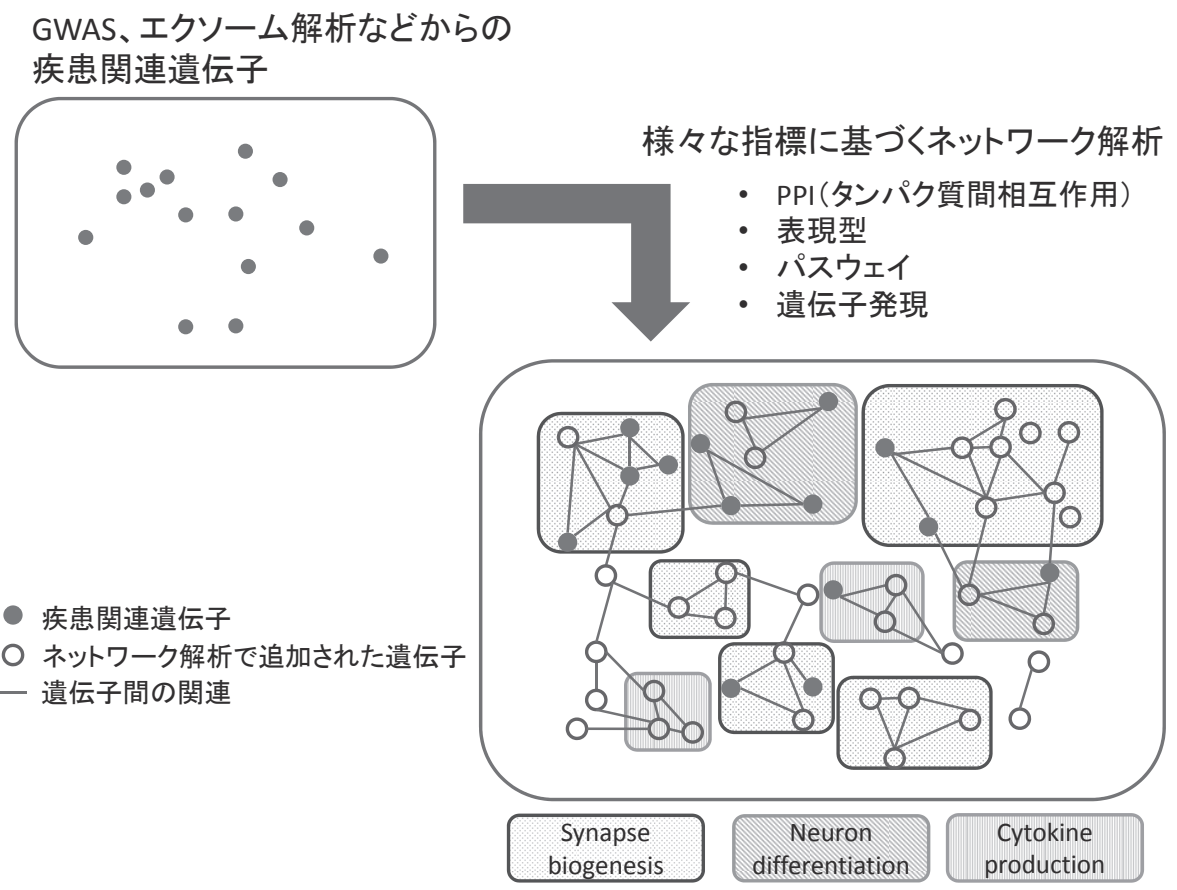

図 1 ヒトゲノム情報を中心としたバイオインフォマティクスを用いた機能解析アプローチ

ットワーク解析を行った。その結果, 軸索誘導, 二ュ 一ロン投射や細胞遊走に関わる遺伝子から構成される クラスターが重要であることが示され，さらに公共の ヒト脳遺伝子発現データベースである Human Brain Transcriptome と統合して評価することにより，その 中のサブクラスターには, 発達期に高発現している遺 伝子が多く含まれることを見出した。 このサブクラス ターにはその de novo 変異が疾患発症に寄与している 可能性の高い遺伝子が多く含まれており, 先に述べた エクソーム解析と同様に統合失調症と発達障害との発 症メカニズムが一部重複する可能性を示唆している (11)。また，同クラスターにはすでに統合失調症との 関連が報告されている mTOR シグナルに関与する遺 伝子も含まれており, 本アプローチは創薬標的を見出 すことに有効であると考えられる.

以上のように, ヒトゲノム情報に遺伝子発現など 様々な情報を統合して解析することで, 創薬標的の探 索だけではなく，従来異なると考えられていた疾患の 発症メカニズムが一部共通しているといった知見も得 られることも期待される。このような研究は, 疾患の 新たな枠組みの構筑, 発症の分子メカニズムに基づい た患者層別化や治療薬の選択へと繋がり, 精神疾創薬 研究の成功確率の向上に貢献すると考えられる.

\section{3. ドラッグリポジショニングからの創薬アプ ローチ}

ドラッグリポジショニングは, 既存薬の新たな適応 疾患を見出す手法である。この手法にバイオインフォ マティクスを応用した事例が近年注目されている。 ド ラッグリポジショニングには, PK/PDが明らかなこと, 安全性が担保されていること, 初期の探索研究や前臨 床やフェーズ I の期間を短縮できること，場合によっ ては臨床研究で既にエビデンスがあること等多くのメ リットがある(12)。これらのメリットから，ドラッグ リポジショニングを専門に取り扱うバイオベンチャー が設立されたり, 製薬会社においても専門部署を設置 したりという動きがある. ドラッグリポジショニング により新たな適応疾患が見出され上市された薬剤は多 く, 乳がん治療薬であるラロキシフェンの骨粗鬆症へ の適応, 高血圧薬であるミノキシジルの秃頭への適応, 抗うつ薬であるデュロキセチンの腹圧性尿失禁への適 応などが例として挙げられる(12)。また, 精神疾患で は，テトラサイクリン系抗菌薬であるミノサイクリン の統合失調症陰性症状への適応や Cox2 阻害薬である セレコキシブの統合失調症への適応が過去に検討され たとの報告もある(13)。これまで新しい疾患への適応 は, 臨床研究や市販後調査によって見出されることが 多かったが，バイオインフォマティクスを応用するこ とにより，より早期の段階でドラッグリポジショニン 
グの可能性を見出すことができると期待されている (14).

バイオインフォマテイクスを用いたドラッグリポジ ショニングへのアプローチは主に 2 つる。一つは,

GWAS 解析結果を利用したアプローチである。これま で，様々な形質に関するGWAS が害施され，公共の GWAS データベースである NCBI の GWAS catalog に はすでに数百種を超える形質や疾患に対する関連遺伝 子情報が収載されている. Sanseau らは公共 GWAS デ 一夕から形質または疾患と遺伝子の関連,

PharmaProjectsから前臨床以降のステージにある薬剤, ターゲット遺伝子および適応疾患との関係を網羅的に 抽出し, 薬剤, 遺伝子, および形質または疾患の関連 性を解析した(15)。抗高脂血症薬であるスタチンは HMGCR をターゲットとする薬剤であるが, GWASに よっても LDLコレステロール值に対する関連遺伝子 として HMGCRが見出され, 形質を改善する薬剤の夕 ーゲット遺伝子と形質の関連遺伝子が一致する例とし て挙げられた。骨粗鬆治療薬のデノスマブの標的は RANKLであるが，GWASによってクローン病の関連 遺伝子であることが見出され，デノスマブがクローン 病治療薬として新たな適応を取得できる可能性が示唆 された，精神疾患においても，新たな原因遺伝子が見 出された際に，その遺伝子を標的とする既存薬があれ ば，精神疾患の治療薬として開発できるかもしれない。

もう一方は遺伝子発現デー夕を用いたアプローチで ある。、イクロアレイに代表される網羅的遺伝子発現
解析は分子生物学研究においては広く普及し, 公共デ ータベースであるNCBIの GEOやEBIの ArrayExpressには 100 万サンプルを超える遺伝子発 現データが登録されている.これらの中で, ドラッグ リポジショニングにおいて特に有用なものはアメリカ Broad研究所が開発している Connectivity map (CMAP) である (16). CMAP は 1000 種を超える市販 薬やッール化合物で乳がん細胞株等に刺激した網羅的 遺伝子発現データベースであり, 研究者自身が取得し たモデル動物や患者サンプル由来の遺伝子発現データ と比較することが可能である (図 2). 比較の結果, 取 得したデー夕とある薬片を作用させた CMAP のデー 夕が正に相関すればその薬剤は疾患を引き起こし, 負 に相関すればその薬剤は疾患を改善する可能性が示唆 され, 新たな疾患への適応が考えられる. 実際に Pfizer 社の Chang らは，アジュバントを投与した OA 疼痛モデルラットの脊䯣後根神経節の遺伝子発現デー 夕を取得し, CMAP との比較解析を実施した (17). そ の結果, OA モデルでの変動と逆相関する化合物とし て $\alpha$ アドレナリン受容体アンタゴニストである抗高 血圧治療薬フェノキシベンザミンが見出され, さらに in vivo にて OA 疼痛への薬効があったことを報告して いる.このように CMAP はドラッグリポジショニン グに有用であると考えられているが，これまではがん 細胞株を用いたデータしかなく，精神疾患領域での利 用には限界があった。しかしながら，CMAP の大規模 な拡張版である LINCS プロジェクトが 2013 年から開

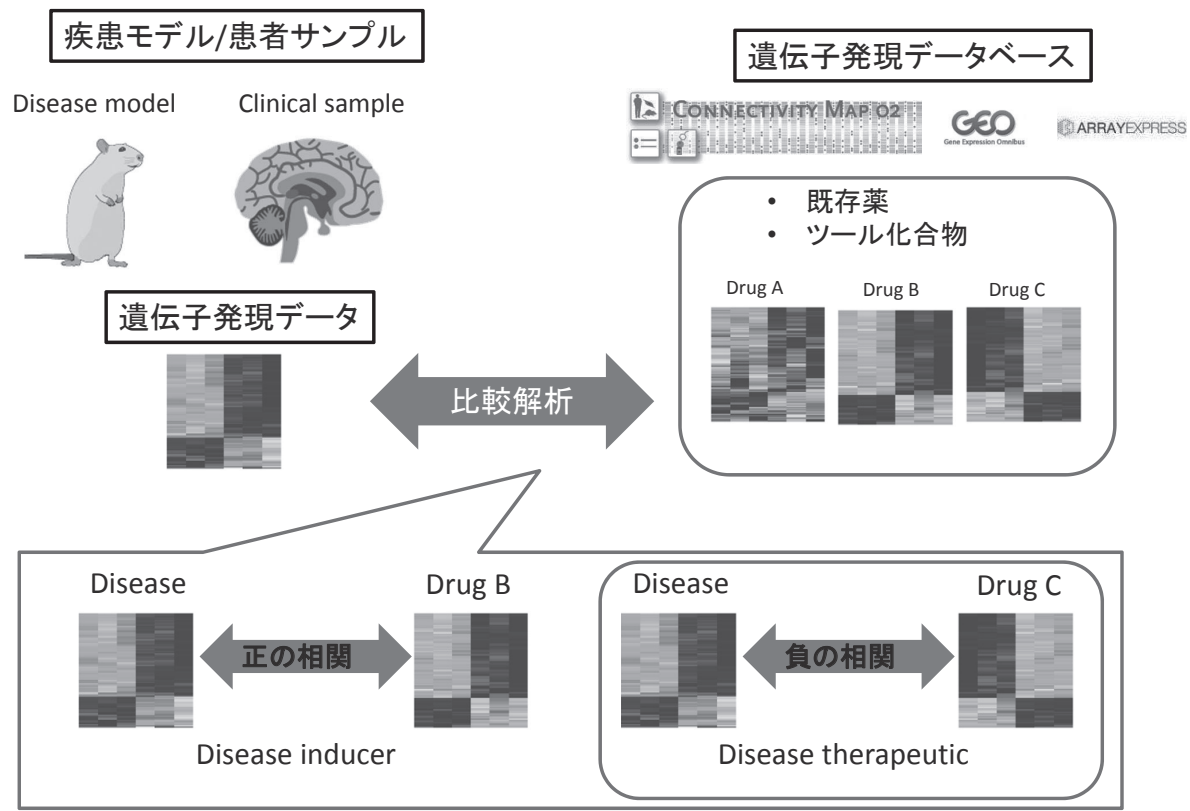

図2 遺伝子発現情報を用いたドラッグリポジショニング 
始され，その中で iPS 細胞由来ニューロンなどの精神 疾患と関連する細胞種の発現情報が取得される予定で ある(18)．LINCS において, 健常人由来の発現プロフ アイルと正に相関し, 精神疾患患者由来の遺伝子発現 プロファイルと逆相関するようなデータが存在すれば, 既存薬の精神疾患に対するドラッグリポジショニング の可能性が期待できる.

また, LINCS では低分子化合物に加えて, 遺伝子の 過剩発現, siRNA 導入による遺伝子ノックダウンに関 する遺伝子発現デー夕も追加されており，ドラッグリ ポジショニングのみならず, 化合物の標的遺伝子や作 用パスウエイの解析においても有用なデータベースと なりうると思われる。

\section{4. おわりに}

本稿では精神疾患におけるバイオインフォマティク スの役割として 2 つのアプローチ, ヒトゲノム情報に 基づく創薬標的探索とドラッグリポジショニングを紹 介した．欧米での患者団体との共同した全ゲノム解析 による疾患原因遺伝子探索や日本での東北メディカル メガバンクをはじめとするコホート研究等, ヒトゲノ ム情報の取得や解析が現在では精力的に実施されてお り, 創薬標的探索やドラッグリポジショニングに有用 な情報が今後益々蓄積することが期待される。また， ゲノム研究を切り口とした疾患研究は NIHM の Insel 所長が提唱する RDoC (Research Domain Criteria) す なわち精神疾患を表現型ではなく, 遺伝子, 神経伝達
物質, 脳機能などのメカニズムベースの疾患として分 類しょうとする試みにも繋がる.

今後, ヒトゲノム情報やその他の生物情報㧍よびそ れらのデー夕を解析するバイオインフォマティクスに より, 精神疾患創薬研究が大きく進展し, 現在の治療 で満たされない患者さんへいち早く新たな治療薬を提 供できることを期待したい.

著者の利益相反 : 桑原佑典, Tore Eriksson, 釣谷克樹 (大正 製薬株式会社).

\section{文献}

1) http://www.fda.gov/downloads/ScienceResearch/SpecialTopics/ CriticalPathInitiative/CriticalPathOpportunities Reports/ UCM077254.pdf

2) Sullivan PF, et al. Arch Gen Psychiatry. 2003;60:1187-1192.

3) Freitag CM. Mol Psychiatry. 2007;12:2-22.

4) Schizophrenia Psychiatric Genome-Wide Association Study (GWAS) Consortium. Nat Genet. 2011;43:969-976.

5) Psychiatric GWAS Consortium Bipolar Disorder Working Group. Nat Genet. 2011;43:977-983

6) Wang K, et al. Nature. 2009;459:528-533.

7) Kwon E, et al. Mol Psychiatry. 2013;18:11-12.

8) Mitsui J, et al. Arch Neurol. 2009;66:571-576.

9) Fromer M, et al. Nature. 2014;506:179-184.

10) Purcell SM, et al. Nature. 2014;506:185-190.

11) Gilman SR, et al. Nat Neurosci. 2012;15:1723-1728.

12) Ashburn TT, et al. Nat Rev Drug Discov. 2004;3:673-683.

13) Torrey EF, et al. Clin Schizophr Relat Psychoses. 2012;5:208-216.

14) MR Hurle, et al. Clin Pharmacol Ther. 2013;93:335-341.

15) Sanseau P, et al. Nat Biotechnol. 2012;30:317-320.

16) Lamb J, et al. Science. 2006;313:1929-1935.

17) Chang M, et al. Mol Pain. 2010. doi: 10.1186/1744-8069-6-56.

18) http://www.lincsproject.org/ 